Justyna Młynarczyk

ORCID: 0000-0002-3936-8828

Uniwersytet Marii Curie-Skłodowskiej w Lublinie

Joanna Parcheta

ORCID: 0000-0003-4053-2338

Uniwersytet Marii Curie-Skłodowskiej w Lublinie

https://doi.org/10.19195/1733-5779.37.12

\title{
Wpływ zmian w działaniach marketingowych firm na zachowania konsumentów w czasie pandemii COVID-19
}

\section{JEL Classification: M31, M37}

Słowa kluczowe: reklama, zachowanie konsumentów, preferencje zakupowe, COVID-19

Keywords: advertising, customer behaviour, shopping preferences, COVID-19

Abstrakt: Istnieje wiele elementów oddziałujących na preferencje zakupowe nabywców, a za jeden z nich można niewątpliwie uznać reklamę. Na przestrzeni czasu zauważalne były jej nowe formy, powstające wskutek panujących trendów czy prognoz. Jednak wybuch ogólnoświatowej pandemii - sytuacji w historii najnowszej bezprecedensowej w swojej skali - spowodował konieczność poszukiwania przez przedsiębiorstwa nowych rozwiązań. Celem artykułu jest omówienie zmian zaobserwowanych w działaniach marketingowych firm podczas pandemii COVID-19, a także ich wpływu na zachowania i preferencje konsumentów. Badanie zostało przeprowadzone z użyciem kwestionariusza ankiety. Na podstawie otrzymanych wyników można wykazać, że niewielka liczba respondentów popierała zaprzestanie promowania się w czasie pandemii. Jednocześnie warto zaznaczyć, że większość z nich zgadzała się ze stwierdzeniem, iż reklama powinna się zmienić i być dostosowana do powagi obecnej sytuacji.

\section{Impact of changes in companies' marketing activities on customer behaviour during the COVID-19 pandemic}

Abstract: There are many elements, which appeal to the buyers' shopping preferences and advertising can undoubtedly be considered as one of them. Over the years, its new forms have been noticeable as a result of the prevailing trends or forecasts. However, the emergence of a new and unknown situation related to the pandemic outbreak made companies look for new solutions. The aim of this article is to discuss the changes which were observed in company marketing activities 
during the COVID-19 pandemic, as well as their impact on customer behaviour and preferences. The study was carried out using a questionnaire. Based on the results, a small number of respondents supported ceasing promotion during the pandemic. Additionally, it is worth noting that most of them agreed with the statement that advertising should be changed and adapted to the gravity of the current situation.

\section{Wstęp}

Jak można zauważyć, na preferencje zakupowe nabywców ma wpływ bardzo wiele czynników, za jeden z nich niewątpliwie można zaś uznać reklamę. Na przestrzeni czasu zauważalne były nowe formy działań marketingowych powodowane pojawiającymi się nieustannie nowymi trendami czy prognozami. Współcześnie natomiast ciągły postęp technologiczny i informacyjny umożliwia zastosowanie nowatorskich form reklamy, które mają jeszcze bardziej zainteresować konsumenta i przekonać go do dokonania zakupu. Niestety pojawienie się wirusa SARS-CoV-2, a co za tym idzie zaistnienie nowej i całkiem nieznanej dotąd sytuacji ogólnoświatowej pandemii, spowodowało potrzebę szukania przez różnego rodzaju przedsiębiorstwa niestosowanych dotąd rozwiązań, czego konsekwencją stały się zmiany w dotychczasowych przyzwyczajeniach konsumentów.

W niniejszej pracy, na podstawie dostępnej literatury i źródeł internetowych, zaprezentowane zostało pojęcie reklamy, cechy z nią związane, a także wybrane formy przekazu reklamowego. Dodatkowo ukazano zaangażowanie przedsiębiorstw z różnych branż $\mathrm{w}$ walkę z panującą obecnie sytuacją. Celem artykułu jest omówienie zmian zaobserwowanych $\mathrm{w}$ działaniach marketingowych firm podczas pandemii COVID-19, a także ich wpływu na zachowania i preferencje konsumentów. W myśl dokładniejszego zaznajomienia się z tematem przeprowadzono badanie z użyciem kwestionariusza ankiety, wykorzystując do tego znaną powszechnie technikę CAWI.

\section{Definicja reklamy i jej cechy}

Reklama jest uznawana za główną formę komunikacji przedsiębiorców z klientami, koncentrując uwagę odbiorców na oferowanym produkcie lub usłudze. Według definicji podanej w 1948 roku przez Amerykańskie Stowarzyszenie Marketingu reklamą jest ,wszelkiego rodzaju płatna forma, nieosobistej prezentacji oraz promocji pomysłów, dóbr lub usług przez określonego sponsora"1.

Działanie marketingowe, którym jest reklama może być opisywane różnorako, w zależności od kontekstu, w jakim zostanie ono wykorzystane. Dla celów niniejszego artykułu należy przyjąć, iż reklama to „zespół działań dążących do skomunikowania się z odbiorcą poprzez różne techniki w celu zwrócenia jego

${ }^{1}$ P. Kotler, Marketing. Analiza, planowanie, wdrażanie i kontrola, Poznań 2005, s. 546. 
uwagi na produkt, usługę, a nawet skonkretyzowaną ideę"2 . Reklamodawcą może być przedsiębiorca oferujący produkt lub usługę, a także instytucja kulturalna czy organizacja społeczna promująca inicjatywy, na rzecz których działa ${ }^{3}$. Kiedy mamy do czynienia z reklamą pewnej idei lub akcji, będzie ona służyła jako narzędzie tak zwanego marketingu społecznego.

Celem reklamy jest dotarcie do obranej przez przedsiębiorcę grupy docelowej i przekazanie jej najważniejszych informacji na temat produktu lub usługi oraz pośrednie wspieranie danej idei. Twórcy reklamy świadomie dobierają formę, treść i medium przekazu, za pomocą którego skutecznie docierają do określonego kręgu osób, jednocześnie zachęcając konsumentów do podjęcia wskazanych działań ${ }^{4}$. Reklama powinna zwracać uwagę klienta na produkt lub markę i wzbudzać wobec nich jego uznanie. Co więcej, dobry przekaz reklamowy powinien powodować $\mathrm{u}$ odbiorcy chęć nabycia i wypróbowania promowanego produktu ${ }^{5}$. Aby jednak reklama spełniała te zadania powinna cechować ją:

— atrakcyjność: przekaz reklamowy musi przyciągać uwagę odbiorcy i w nietuzinkowy sposób informować o produkcie;

— sugestywność: reklama powinna w jak największym stopniu przekonywać do kupna lub skorzystania z usługi, a jej argumenty powinny być dostosowane do naszej grupy docelowej;

— zrozumiałość: przez przekazywane informacje powinniśmy wytworzyć w odbiorcy założone przez nas wyobrażenie o produkcie, klient nie powinien mieć problemów w interpretacji naszego przekazu;

— zapamiętywalność: łatwości zapamiętywania reklamy sprzyja wielokrotne jej powtarzanie, stosowanie rymów i skojarzeń;

— zwięzłość: przekaz reklamowy powinien być krótki i skupiający uwagę na najważniejszych cechach produktu;

— oryginalność: sposób promowania oferowanego dobra powinien wyróżniać się na tle konkurencji i być niepowtarzalny;

— aktualność: reklama powinna być dostosowana do panującej sytuacji społeczno-ekonomicznej ${ }^{6}$.

${ }^{2}$ https://flstrefa.pl/reklama.html (dostęp: 17.12.2021).

${ }^{3}$ K. Starzyńska, Charakterystyka reklamy w oparciu o jej genezę i cechy, „Zeszyty Naukowe Uniwersytetu Przyrodniczo-Humanistycznego w Siedlcach. Seria: Administracja i Zarządzanie” 2015, nr 106, s. 278.

4 Ibidem.

${ }_{5}$ M. Mrożek, Marketing i sprzedaż produktów pochodzacych z gospodarstwa rolnego, Radom 2020, s. 14.

${ }^{6}$ R. Nowacki, Reklama, Warszawa 2005, s. 75. 


\section{Wybrane formy przekazu reklamowego}

Podczas planowania kampanii reklamowej istotną rolę odgrywa tak forma przekazu, jak i jego nośnik. Formą przekazu reklamy jest ,jedna z fizycznych możliwości eksponowania treści reklamowych w danym medium"7. Z kolei wszelkie formy nadawania przekazów reklamowych, które są dostosowane do konkretnych mediów i środków reklamy, to nośniki reklamy ${ }^{8}$. Wśród najpopularniejszych form przekazu znajdują się reklamy telewizyjne, reklamy radiowe i reklamy internetowe. Medium, jakim jest radio, ma wiele zalet, dzięki czemu wciąż nie traci na swojej popularności. Przede wszystkim różnorodność rozgłośni radiowych umożliwia dotarcie przekazu reklamowego do wąsko określonej grupy docelowej. $Z$ tego powodu dla reklamodawców, którzy zamierzają ograniczyć krąg potencjalnych odbiorców do osób z wybranego terenu, szczególnie ważna będzie współpraca ze stacjami radiowymi o zasięgu regionalnym. Ponadto radio może pełnić funkcję medium podstawowego — gdy jest to główny kanał dystrybucji treści reklamowych, lub medium wspomagającego ${ }^{9}$. Reklama radiowa przez swoją formę może dotrzeć do słuchacza niezależnie od tego czym zajmuje się on w danej chwili — jedynym warunkiem jest posiadanie włączonego odbiornika. W porównaniu do reklamy telewizyjnej, zarówno koszty produkcji, jak i koszty emisji są niskie. Nośnikami w przypadku reklam radiowych są audycje, spoty reklamowe i programy.

Za najbardziej sugestywną formę reklamy uważana jest jednak reklama telewizyjna. Skupiając w sobie trzy elementy: słowo, dźwięk i obraz, intensywnie wpływa na emocje i podświadomość odbiorców. Z psychologicznego punktu widzenia im więcej zmysłów zostanie zaangażowanych, tym silniejszy wizerunek marki zostanie wykreowany w umysłach odbiorców ${ }^{10}$. Reklamę telewizyjną charakteryzuje zatem wysoki stopień perswazji, zaangażowanie emocjonalne odbiorcy oraz łatwość prezentacji i przeznaczenia oferowanego produktu. Do zalet telewizji jako medium reklamowego zaliczyć można także jej duży zasięg oraz liczne grono oglądających. Dzięki temu wysoki koszt produkcji i wykorzystywanego czasu antenowego jest w pewnym stopniu rekompensowany, gdyż koszt dotarcia do jednego potencjalnego klienta okazuje się relatywnie niski. W odróżnieniu od reklam radiowych, przekazy telewizyjne cechują się niską selektywnością geograficzną

7 D. Filar, Współczesny marketing. Skuteczna komunikacja i promocja, [w:] Podręcznik dla studentów specjalności Komunikacja urzędowa i biznesowa, red. D. Filar, Lublin 2012, s. 274.

8 Z. Pierścionek, S. Jurek-Stępień, Czynniki sukcesu polskich przedsiębiorstw na rynkach Unii Europejskiej, Warszawa 2006, s. 32-36.

9 A. Radzikowski, Reklama internetowa jako istotny czynnik w skutecznej promocji marki (1), https://telefirma.pl/reklama-internetowa-jako-istotny-czynnik-skutecznej-promocji-marki-1 (dostęp: 11.03.2021).

10 M. Lindstrom, Dziecko reklamy, Warszawa 2005, s. 141. 
i demograficzną ${ }^{11}$, komunikaty marketingowe są więc zazwyczaj kierowane do ogółu społeczeństwa. Reklama telewizyjna przyjmuje najczęściej formę spotu, lokowania produktu podczas emisji wszelkich programów telewizyjnych, filmów i seriali. Szczególną formą reklamy telewizyjnej jest także sponsoring telewizyjny, czyli objęcie patronatem transmitowanego wydarzenia ${ }^{12}$.

Niemniej jednak obecnie jednym z największych mediów reklamowych jest internet, który jest narzędziem realizacji nowej gałęzi gospodarki, określanej jako e-commerce ${ }^{13}$. Wybuch pandemii COVID-19 wymusił na nas zmianę trybu życia i w znacznym stopniu przeniósł naszą edukację, pracę oraz wszelkie inne aspekty życia społecznego do świata wirtualnego. To zaś wpłynęło bezpośrednio na zwiększenie zasięgu reklamy internetowej. Internet ma jednocześnie cechy medium masowego i medium komunikacji bezpośredniej, co umożliwia dystrybucję przekazu zarówno do szerokiego grona osób, jak i do indywidualnego odbiorcy. W sieci to głównie oglądający, a nie reklamodawca decyduje o tym, czy zapozna się z daną informacją. Dlatego też twórcy reklamy internetowej przykładają szczególną wagę do zaintrygowania odbiorcy, by przekonać go chociażby do kliknięcia w banner i zgłębienia prezentowanych na nim informacji ${ }^{14}$.

Najbardziej popularnym obecnie nośnikiem reklamowym online są strony internetowe. Pomiędzy zawartymi na nich treściami można dostrzec wszelkie formy graficznej e-reklamy. Może być to reklama bannerowa, przybierająca czy to formę statyczną (jeden, nieruchomy obraz), czy też dynamiczną (proste animacje w formacie gif lub krótkie filmiki). Popularną formą reklamy stała się także reklama winietowa, pod której pojęciem kryją się reklamy pełnoekranowe na komórki wyświetlane między ładowaniem stron ${ }^{15}$. Wielu przedsiębiorców tworzy własne strony internetowe, stanowiące ich wizytówkę, a zarazem umożliwiające klientowi zapoznanie się z prezentowaną tam ofertą - witryny internetowe często bowiem pełnią również funkcję sklepu internetowego. Każda strona internetowa powinna mieć przemyślany i estetyczny układ graficzny, zapewniać przejrzystość prezentowanych na niej treści oraz umożliwiać czytelnikowi łatwość w poruszaniu się pomiędzy jej sekcjami.

Warto w tym miejscu wyróżnić marketing w mediach społecznościowych (ang. social media marketing). Jest to dziedzina marketingu internetowego polegająca

11 D. Dennison, L. Tobey, Podręcznik reklamy, Lublin 1997, s. 192.

12 M. Strużycki, T. Heryszek, Nowoczesna reklama na współczesnym rynku, Warszawa 2007, s. $62-63$.

${ }^{13}$ I. Dudzik-Lewicka, M. Hofman-Kohlmeyer, Postrzeganie i skuteczność poszczególnych form reklamy internetowej, „Zeszyty Naukowe Wyższej Szkoły Humanitas. Zarządzanie” 2015, nr 4, s. 209.

${ }^{14}$ M. Habryń, Formy reklamy w Internecie, [w:], Estetyka reklamy: reklama w rzeczywistości — rzeczywistość w reklamie, red. M Ostrowicki Kraków 2002, s. 285.

15 https://mobirank.pl/2016/04/28/reklamy-mobilne-adsense-na-poziomie-strony/ (dostęp: 12.03.2021). 
na pośredniej promocji w drodze komunikacji z potencjalnymi klientami za pośrednictwem serwisów społecznościowych czy też blogów przez umieszczanie lub wymianę artykułów, filmików lub obrazów ${ }^{16}$. Skuteczna strategia marketingowa w mediach społecznościowych, to jest strategia wykorzystująca możliwości prezentowane przez Facebook czy Instagram, jest podstawowa w kwestii wzrostu sprzedaży. Najpowszechniejszym narzędziem marketingu w mediach społecznościowych jest prowadzenie bloga firmowego, który w głównej mierze pomaga w budowaniu pozytywnego wizerunku firmy i tworzeniu się społeczności klientów oraz może stanowić kanał komunikacyjny między klientem a producentem ${ }^{17}$. Od strony internetowej wyróżnia go mniej oficjalny charakter, wpisy mogą być komentowane, dzięki czemu ma on charakter bardziej interaktywny ${ }^{18}$. Zaletą bloga jest to, że jego prowadzenie nie wymaga dużych nakładów finansowych oraz szczególnych umiejętności informatycznych. Niemniej jednak jest to zajęcie bardzo czasochłonne — zanim bowiem zacznie on pełnić swoją funkcję marketingową, konieczne jest, aby najpierw zyskał na popularności.

Coraz częściej przedsiębiorcy sięgają również po e-mail marketing — rodzaj marketingu bezpośredniego wykorzystujący pocztę elektroniczną. E-mailing charakteryzuje się szybkim kontaktem z potencjalnym klientem, niskim kosztem przekazu oraz targetowaniem wiadomości, czyli kierowaniem jej do obranej grupy odbiorczej ${ }^{19}$. Najczęściej wykorzystywanym narzędziem e-mail marketing są biuletyny elektroniczne, zwane powszechnie newsletterami, dostarczanymi za pośrednictwem poczty elektronicznej do określonych odbiorców, którzy uprzednio świadomie wyrazili zgodę na taki rodzaj działań marketingowych ${ }^{20}$. W newsletterach wysyłane są do klientów powiadomienia o aktualnie dostępnych produktach, wprowadzanych do oferty nowościach i bieżących promocjach. Najprostszym i najczęściej wykorzystywanym sposobem na zgromadzenie bazy adresów e-mail przez przedsiębiorcę jest oferowanie rabatu lub bonusu w zamian za rejestrację do newslettera, którego regularne wydawanie pomaga w zbudowaniu grona stałych klientów.

16 A. Piosik, Wspótczesne formy komunikacji w marketingu — guerilla marketing, ,Zeszyty Naukowe Uniwersytetu Szczecińskiego. Problemy Zarządzania, Finansów i Marketingu” 2012, nr 21, s. 105.

${ }^{17}$ M. Mrożek, op. cit., s. 17.

18 J. Muszyńska, Jak prowadzić tani i skuteczny marketing w czasach kryzysu gospodarczego, Warszawa 2010, s. 15.

19 P. Rusiecki, Skuteczny mailing oparty na podstawowych zasadach e-mail marketingu, [w:] Systemy Wspomagania Organizacji SWO 2007, red. T. Porębska-Miąc, H. Sroka, Katowice 2007, s. 279.

${ }^{20}$ M. Furmankiewicz, P. Ziuziański, Newsletter jako efektywne narzędzie e-mail marketingu $w$ zarzadzaniu relacjami z klientami, [w:] Rola informatyki w naukach ekonomicznych i spolecznych. Innowacje i implikacje interdyscyplinarne, t. 1, red. Z. E. Zieliński, Kielce 2013, s. 327. 


\section{Zaangażowanie firm w walkę z COVID-19}

Wybuch ogólnoświatowej pandemii spowodował konieczność poszukiwania przez przedsiębiorstwa nowych rozwiązań. Dotyczyło to w szczególności różnego rodzaju działań reklamowych czy też marketingowych. Można powiedzieć, że stawiane współczesnej rzeczywistości wyzwania powodowały potrzebę ewoluowania znanych powszechnie sposobów komunikacji marketingowej — począwszy od zwiększenia liczby działań promocyjnych w niektórych sektorach rynku, przez utrzymanie kontaktu z konsumentami na dotychczasowym poziomie aż do ograniczenia czy wręcz całkowitego zaprzestania kampanii reklamowych ${ }^{21}$.

Większość marek wybierała perspektywę prowadzenia dalszych działań marketingowych, aczkolwiek prezentowane treści dostosowywała do panujących realiów. Jedne z nich dotyczą zjawiska tak zwanego re-design logo, czyli jego zmiany wyglądu celem połączenia wizerunku marki z silnym przekazem określonych wartości. Prekursorem tego trendu był słoweński grafik Jure Tovrljan, który postanowił przerobić kilkanaście najbardziej znanych logotypów w taki sposób, aby zachęcały ludzi do pozostawania w domach i przestrzegania, jak również respektowania wprowadzonych zasad bezpieczeństwa, w tym szczególnie zachowania bezpiecznej odległości od innych osób ${ }^{22}$. Wśród edytowanych przez niego logo znalazły się takie marki jak Mastercard czy Starbucks, a nawet symbol igrzysk olimpijskich i NBA. Niektóre firmy zaczęły wykorzystywać ten nowatorski pomysł - chociażby McDonald's. Zmienił on swoje logo zawierające dwa połączone łuki tworzące charakterystyczną literę M na takie, w którym łuki te są rozdzielone. Podobnie w wypadku producenta Audi, który w jednej z reklam zazębiające się do tej pory pierścienie przedstawił oddzielnie.

W czasie pandemii twórcy reklam zaczęli chętnie sięgać po dość uniwersalne i przyjemne w obsłudze narzędzia, czego skutkiem były często zauważalne w dużej ilości, wręcz dominujące w mediach reklamy „,winietkowe”, oparte na montażu wcześniej przygotowanych materiałów video w spójną całość. Mimo że każda z takich form przekazu ma na celu odwzorować jak najdokładniej panującą wokół rzeczywistość, to w chwili oglądania wydają się być do siebie bardzo podobne, a w niektórych momentach — wręcz identyczne. Przykładem takich reklam jest akcja „\#Milion sposobów na nudę” promowane przez Lotto, jak również zaproszenie konsumentów przez producenta Guinness do wspólnego obchodzenia Dnia Świętego Patryka w swoich domach w sposób jak najbardziej bezpieczny ${ }^{23}$.

Mimo podobieństwa tego typu reklam przez wzgląd na fakt, że opierają się na takim samym przekazie, przez co można uznać je za powtarzalne, to zdarza się

21 https://www.ipsos.com/pl-pl/reklama-w-dobie-covid-19 (dostęp: 17.12.2020).

22 https://www.marketing-interactive.com/designer-behind-viral-covid-19-redesigned-logos-grabs-attention-of-major-brands (dostęp: 17.12.2020).

$23 \mathrm{https}$ //digitalmarketinginstitute.com/blog/5-inspiring-covid-19-marketing-campaigns (dostęp: 17.12.2020). 
pomijać kampanie reklamowe będące perełkami. Przykładem są chociażby reklamy Ubera, w szczególności „Don’t move” czy „Thank you for not riding”. W spocie zwraca uwagę fakt, że firma w jasny sposób odradza klientom korzystanie ze swoich usług, co można uznać za dość niestandardowy przekaz. Zastosowano w nich ponadto rozwiązanie obserwowane również w spotach innych marek — na przykład Jack Daniels czy T-Mobile - czyli przedstawienie codziennych trosk, wyzwań i aktywności podejmowanych przez społeczeństwo w trakcie przymusowego pozostania w domu. Dodatkowo w kampaniach tych hasło ujawniane jest dopiero pod koniec emitowanego materiału, co nie wydaje się dość oczywistym wyborem ${ }^{24}$.

Warto wyróżnić szczególnie kreatywny pomysł na reklamę stworzony przez markę Dove. Dzisiaj siła kreacji ukazywana w spotach promocyjnych jest niezwykle ważnym ich aspektem — zwłaszcza przy poruszaniu istotnych kwestii społecznych, by z jednej strony potraktować temat w sposób emocjonalny, z drugiej zaś - utrzymać dość prostą formę przekazu. Kampania „Prawdziwe piękno”, znana też pod angielską nazwą „Courage is beautiful”, nie tylko podkreślała znaczącą rolę pracowników medycznych w walce z pandemią, lecz także zachęcała do pozostania $\mathrm{w}$ domach i przestrzegania nałożonych ograniczeń, ale także miała na celu pomoc potrzebującym ${ }^{25}$. Tego typu inicjatywy pozwalają wzbudzić w nabywcach swego rodzaju poczucie bezpieczeństwa oraz pobudzić ich zaangażowanie w walkę z koronawirusem.

Część koncernów zdecydowała się jednak zawiesić swoje działania marketingowe. Przykładem może być tu chociażby Coca-Cola, która zrezygnowała z wszelkiego rodzaju aktywności promocyjnych, a budżet przeznaczony na te działania został przekazany na wsparcie walki z koronawirusem ${ }^{26}$. Taka forma pomocy nie przeszła obojętnie wśród konsumentów, oczekujących od światowych marek realnych działań, a tym samym potrafiących je docenić. Pozycja Coca-Coli na rynku wydaje się tak mocna, że mimo niepowiązania $\mathrm{z}$ tematyką zdrowia jest w stanie właśnie tego typu akcjami pozostawać dalej w świadomości klientów i budować pozytywny wizerunek swojej marki. Z kolei inne przedsiębiorstwo - Grupa L'Oréal - część produkcji skierowało na wytworzenie środków do dezynfekcji, a dodatkowo zainicjowało europejski plan solidarnościowy mający na celu wsparcie szpitali i domów opieki w walce $\mathrm{z}$ pandemią ${ }^{27}$. Marka ta wstrzymała także

24 https://www.wirtualnemedia.pl/artykul/najlepsze-reklamy-powstale-w-czasie-pandemii-koronawirusa (dostęp: 17.12.2020).

$25 \mathrm{https} / /$ www.graziame.com/style/beauty/why-doves-courage-is-beautiful-campaign-is-important (dostęp: 17.12.2020).

${ }^{26} \mathrm{https} / /$ www.coca-cola.pl/poznaj-nas-lepiej/komunikaty-prasowe/2020/wstrzymujemy-nasze-dzialania-reklamowe-koronawirus?fbclid=IwAR0OCI_AFII9KRUBFH4LC9ELmfMj65LusLtaafsE25pIVio6SfRpSwSzj9g (dostęp: 17.12.2020).

27 https://www.loreal.com/pl-pl/poland/articles/group/our-response-to-covid-pl/ (dostęp: 17.12.2020). 
swoje działania marketingowe w telewizji, a jako spot reklamowy wykorzystany został materiał wideo udostępniony na stronie internetowej YouTube, w którym znana aktorka pokazywała, w jaki sposób samodzielnie ufarbować włosy w domu. Tym samym była to swego rodzaju odpowiedź na wprowadzenie restrykcyjnych obostrzeń i zamknięcie salonów fryzjerskich.

\section{Metodyka badania}

Badanie zatytułowane Wpływ zmian $w$ działaniach marketingowych firm na zachowania konsumentów w czasie pandemii COVID-19 miało charakter ilościowy i zostało zrealizowane przy użyciu metody badawczej CAWI (Computer Assisted Web Interview) z wykorzystaniem formularzy Google. Zastosowanie tej techniki umożliwiło skuteczne, a przede wszystkim bezpieczne przeprowadzenie całego procesu badawczego zarówno z perspektywy badaczy, jak i respondentów.

Kwestionariusz ankiety składał się z czterech pytań jednokrotnego lub wielokrotnego wyboru, trzech rozbudowanych tabel wartościujących oraz jednego pytania otwartego. Badanie skierowane było zarówno do kobiet, jak i mężczyzn w wieku 18-29 lat i zostało przeprowadzone na przełomie lutego i marca 2021 roku. Próba badawcza, przy zastosowaniu metody doboru celowego, wyniosła 107 osób.

Rozkład próby prezentował się w następujący sposób:

— największą grupę referentów stanowiły kobiety — 81\% (w liczbie 87 osób), mężczyźni zaś 19\% (w liczbie 20 osób);

— ze względu na miejsce zamieszkania: wieś - 38\% (w liczbie 41 osób), miasto poniżej 100 tys. mieszkańców — 28\% (w liczbie 30 osób), miasto poniżej 250 tys. mieszkańców - 12\% (w liczbie 13 osób), miasto poniżej 500 tys. osób 14\% (w liczbie 15 osób) i miasto powyżej 500 tys. mieszkańców — 8\% (w liczbie 8 osób);

— ponad połowa badanych (65\%) deklarowała wykształcenie wyższe, natomiast pozostali respondenci (35\%) wykształcenie średnie;

— status studenta/ki był najczęściej deklarowanym przez referentów (74\%), co piąty zaś wskazywał, że pracuje; status bezrobotnego, ucznia/uczennicy czy też jednocześnie studiującego i zatrudnionego wskazywało $2 \%$ badanych.

\section{Wyniki badania własnego}

Respondenci w pierwszej kolejności zostali zapytani o to, jaka była najczęstsza forma reklamy, z którą mieli styczność podczas pandemii. Zdecydowana większość, bo aż 78\% badanych odpowiedziała, że była to reklama internetowa. Kolejnym rodzajem była reklama telewizyjna, którą wskazało 20\% respondentów, a zaledwie $2 \%$ ankietowanych odpowiedziało, że najczęściej spotykaną przez nich formą przekazu reklamowego była reklama radiowa (rys. 1). W związku z tym, że 
konsumenci w wyniku pracy i nauki zdalnej spędzają znacznie więcej czasu $\mathrm{w}$ domu, straciła na znaczeniu reklama wielkoformatowa, w tym billboardy, a także reklama papierowa prezentowana $\mathrm{w}$ prasie czy też $\mathrm{w}$ formie ulotek.

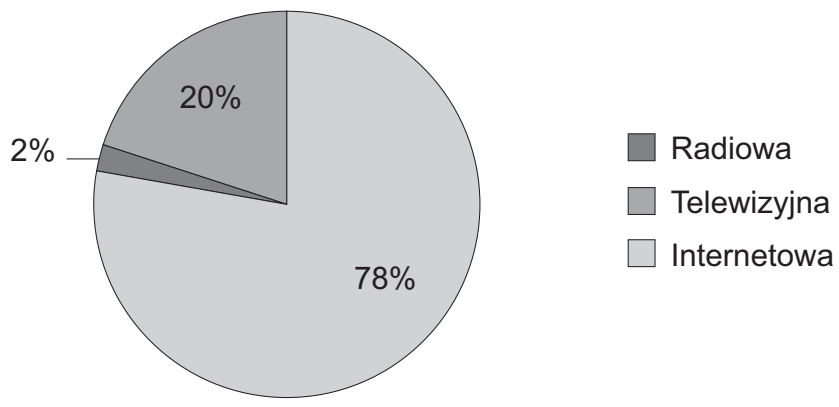

Rysunek 1. Jaka była najczęstsza forma reklamy, z którą miał/a Pan/i styczność podczas trwania pandemii?

Źródło: opracowanie własne na podstawie wyników przeprowadzonych badań.

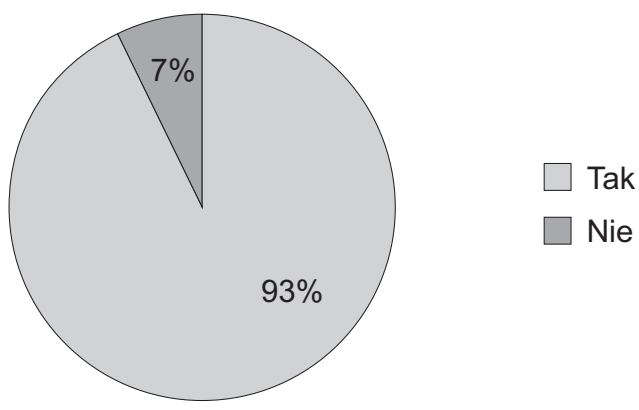

Rysunek 2. Czy dostrzegł/a Pan/i nawiązania do pandemii COVID-19?

Źródło: opracowanie własne na podstawie wyników przeprowadzonych badań.

Ponad $90 \%$ osób w spotykanych reklamach dostrzegło nawiązania do pandemii COVID-19; związków tych nie odnotowało tylko 7\% badanych (rys. 2). Świadczy to o tym, że reklamodawcy w swoich kampaniach często odnoszą się do obecnej sytuacji i wykorzystują motyw pandemii w ich treści.

Pytanie „Czy Pana/i zdaniem działania marketingowe mogą opierać się na pokazaniu zaangażowania firmy w walkę z COVID-19?" zostało przedstawione respondentom $\mathrm{w}$ formie skali rang. Ich zadaniem było odpowiedzieć, oceniając swoją aprobatę na wyżej postawione pytanie. Zgodnie z ustalonym kluczem ( 1 - zdecydowanie nie; 2 - raczej nie; 3 - ani tak, ani nie; 4 - raczej tak; 5 - zdecydowanie tak) najwięcej odpowiedzi zebrała opcja neutralna ,ani tak, ani nie", za którą opowiedziało się $40 \%$ respondentów. Świadczy to o tym, iż 
duża część osób objętych badaniem nie ma zdania na ten temat lub zauważalny jest pewien dylemat moralny. Spośród pozostałych odpowiedzi przeważa jednak przekonanie, że działania marketingowe mogą opierać się na pokazaniu zaangażowania danego przedsiębiorstwa w walkę z COVID-19. Odpowiedzi „,raczej tak” udzieliło $36 \%$ badanych, odpowiedzi zaś ,zdecydowanie tak” 13\%. Pozostałe warianty odpowiedzi, które świadczyły o negatywnym nastawieniu do pokazywania zaangażowania firm $\mathrm{w}$ walkę z pandemią, zostały wybrane tylko przez $10 \%$ osób objętych ankietą.

Respondenci zostali zapytani także o to, czym powinna cechować się reklama w analizowanym czasie. Odpowiedzieli jednoznacznie, że powinna ona dostarczać informacji o wszelkich udogodnieniach dla konsumenta, a przede wszystkim — pełnić swoją podstawową funkcję — informacyjną. Wśród odpowiedzi wyróżnia się także zdanie, że przekaz reklamowy powinien być dostosowany do panujących realiów. Szersze spektrum odpowiedzi obejmuje natomiast kwestię wpływu reklamy na emocje odbiorców. W tym przypadku pojawiły się opinie skrajne negatywne, wskazujące, że reklama zdecydowanie nie powinna wywierać wpływu na psychikę odbiorcy, co z kolei może się wiązać z obawami odbiorców przed poddawaniem ich emocjonalnej manipulacji. Mimo to zdaniem większości reklama powinna podnosić na duchu, zawierać elementy humorystyczne i dostarczać rozrywki.

Istotną dla przeprowadzonego badania była kwestia dotycząca działań marketingowych zauważalnych przez konsumentów i podjętych przez przedsiębiorców na przełomie ostatniego roku (rys. 3). Bez wątpienia największym echem odbiła się promocja akcji „Zostań w domu”, którą wskazało aż 86\% osób ankietowanych. Kolejnym najczęstszym aspektem, zaobserwowanym w ciągu ostatniego roku, było dostosowanie sposobu obsługi klienta do aktualnych zaleceń sanitarnych. Natomiast na reorganizację stanowisk obsługi i zmianę sposobu przyjmowania klientów zwróciło uwagę $85 \%$ badanych. Zmiany te wynikają z przyjętych w danym państwie zasad bezpieczeństwa sanitarnego i obowiązywania odgórnych wytycznych.

Przypominanie o zachowywaniu dystansu społecznego wskazało $65 \%$ osób, co świadczy o tym, że kampanie reklamowe promujące konkretne zachowania w społeczeństwie okazały się skuteczne i zostały zapamiętane przez ogół odbiorców. Zmiana oferty produktowej bądź usługowej została dostrzeżona przez 53\% respondentów, a zwrócenie uwagi konsumentów na tego rodzaju działanie przedsiębiorców mogło wynikać z konieczności zmiany swoich przyzwyczajeń względem rodzaju oferowanych im produktów czy usług, jak również sposobu ich dostarczania.

Wśród grupy badanych aż 30\% dostrzegło zmianę ilości prowadzonych działań marketingowych. Mowa tu zarówno o zwiększeniu działań marketingowych mających na celu wzrost liczby odbiorców reklamy — jak również ich zmniejszeniu, poprzez ograniczenie ich ilości, na przykład wskutek wykluczenia z kampanii jednego z medium. Wiąże się to z kolejnym działaniem reklamodawców zauważonym również przez 30\% respondentów, czyli zmianą miejsca publikacji reklamy, na przykład przeniesienia jej do internetu. Przyczyną tych zmian jest niewątpliwie 
konieczność adaptacji do obowiązujących restrykcji, a także reakcja na potrzeby konsumentów, którzy w wyniku wybuchu pandemii zmienili tryb swojego życia.

Wspieranie działań grup najbardziej narażonych na zakażenie czy też pracujących na „pierwszej linii” wskazał co trzeci badany. Firmy w ten sposób chcą wyrazić szczególne uznanie dla pracowników służby zdrowia i innych organizacji zaangażowanych w pomoc oraz zapewnianie bezpieczeństwa w obecnym, trudnym czasie pandemii. Dla właścicieli przedsiębiorstw okazanie empatii jest poniekąd sposobem na ocieplenie wizerunku marki czy też zyskanie szacunku u klientów. Popularny staje się także angaż w działania marketingowe osób funkcjonujących w przestrzeni publicznej - na to działanie zwróciło uwagę $21 \%$ respondentów. Wciągnięcie do kampanii społecznej znanej osoby, która często jest dla określonej części społeczeństwa inspiracją i wzorem do naśladowania, to doskonały sposób na dotarcie z przekazem do szerokiego grona odbiorców, a także zwiększenie szans na osiągnięcie założonego dla konkretnej akcji promocyjnej celu.

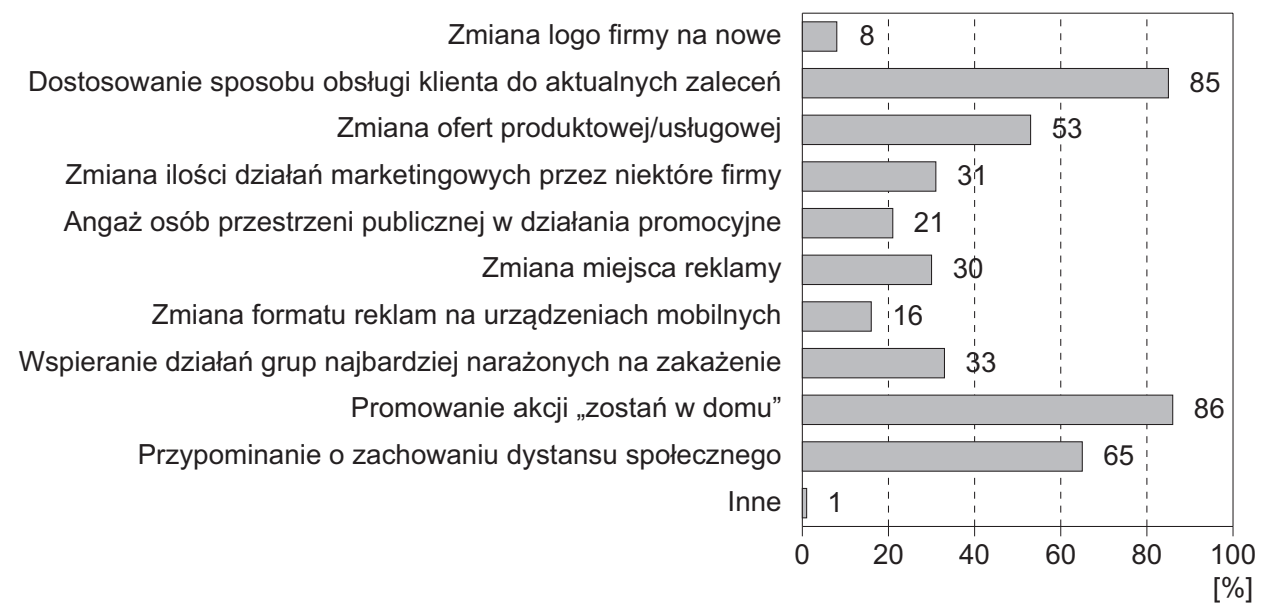

Rysunek 3. Które z wymienionych działań przedsiębiorców zauważył/a Pan/i w ciągu ostatniego roku?

Źródło: opracowanie własne na podstawie wyników przeprowadzonych badań.

Pozostałe dwie zmiany w działaniach marketingowych, które zostały wskazane $\mathrm{w}$ ankiecie, to zmiana formatu reklam na urządzeniach mobilnych oraz zmiana logo na nowe - uzyskały one odpowiednio 16\% i $8 \%$ odpowiedzi. Prawdopodobnie nie są one wystarczająco widoczne w przestrzeni publicznej, przez co ich dostrzeżenie wymaga skupienia szczególnej uwagi na danej marce czy jej reklamie. Działania te nie były tak powszechne wśród marketingowców jak chociażby adaptacja treści reklam do zmieniającej się rzeczywistości, zatem uzyskane w ankiecie wyniki można uznać za relatywnie wysokie. 
Na pytanie „Czy Pana/Pani zdaniem firmy powinny zaprzestać działań promocyjnych z powodu trwającej pandemii?" aż $92 \%$ osób odpowiedziało przecząco. $\mathrm{Za}$ wstrzymaniem tego typu działań opowiedziało się pozostałe $8 \%$ ankietowanych (rys. 4).

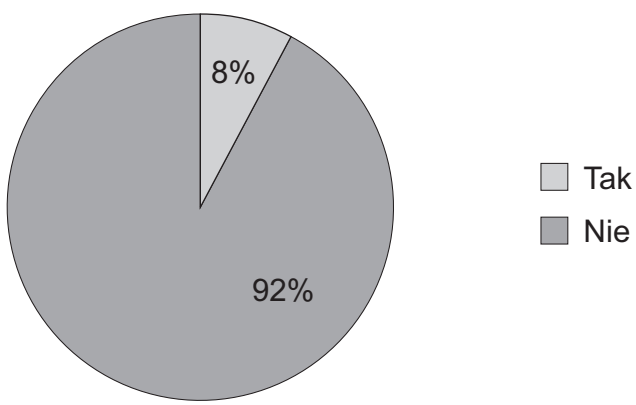

Rysunek 4. Czy Pana/Pani zdaniem firmy powinny zaprzestać działań promocyjnych z powodu trwającej pandemii?

Źródło: opracowanie własne na podstawie wyników przeprowadzonych badań

W zależności od zadeklarowanej wcześniej odpowiedzi poproszono respondentów o uzasadnienie swojego wyboru w kwestii zaprzestania lub kontynuowania wyżej wymienionych działań promocyjnych. Wśród argumentów pojawiły się zarówno takie, które skupiają się na kwestiach społecznych, jak odnoszące się do czynników ekonomicznych.

W wypadku wybrania odpowiedzi wskazującej na potrzebę kontynuacji prowadzonych kampanii reklamowych przeważało stwierdzenie, że zaprzestanie ich wśród przedsiębiorców mogłoby prowadzić do upadku biznesów. Dlatego też powinny być one utrzymane, szczególnie w czasie wzrastającego bezrobocia i mając w perspektywie zapowiadany przez wielu ekonomistów kryzys gospodarczy. Oprócz podstawowego celu, jakim jest możliwość zaprezentowania swojego produktu lub usługi, badani w reklamie widzą szansę na utrzymanie pozycji rynkowej marki oraz zyskanie nowych klientów, a co za tym idzie zwiększenie przychodów przedsiębiorstwa. Respondenci zwrócili także uwagę na zależność między wzmożonymi działaniami promocyjnymi a ich pozytywnym wpływem na gospodarkę państwa. W wielu odpowiedziach podkreślano znaczenie reklamy internetowej, która zachęca do zakupów w sieci, bez konieczności wychodzenia $\mathrm{z}$ domu. Ta forma promocji, ich zdaniem, powinna w szczególności być kierowana do osób, które wciąż są sceptycznie nastawione do dokonywania zakupów online.

Wśród osób ankietowanych istnieje także przekonanie, że marketing to podstawa prowadzenia biznesu niezależnie od czasu i warunków, w których przyszło żyć. Zdaniem większości badanych nie istnieją przeciwwskazania do kontynuowania działań promocyjnych w czasie pandemii COVID-19, o ile przekazy rekla- 
mowe nie wykorzystują jej motywu dla osiągnięcia zysków kosztem porzucenia zasad etyki. Pojawiły się także opinie, iż przemyślane działania promocyjne, mogą wręcz pomagać $\mathrm{w}$ walce $\mathrm{z}$ pandemią poprzez zwiększanie świadomości społeczeństwa oraz przypominanie o obowiązujących obostrzeniach i konieczności przestrzegania zasad reżimu sanitarnego. Jest to przykład wykorzystania reklamy jako narzędzia marketingu społecznego, który ma na celu nakłonić odbiorców do działania zgodnie z przyjętą ideą. Za tym, aby kampanie reklamowe były kontynuowane opowiedziały się także osoby uważające, że reklama może wywoływać pozytywne emocje, podnosić na duchu i dawać nadzieję na lepsze jutro.

Wśród odpowiedzi badanych, którzy byli za wstrzymaniem działań marketingowych dominujące było przekonanie, że promowanie swoich produktów wykorzystując w tym celu problem pandemii jest nieetyczne i negatywnie wpływa na społeczeństwo. Jako przykład zostały podane reklamy lotów za granicę, co w obecnej sytuacji nie jest zalecane. Zdaniem większości osób z tej grupy respondentów temat będący źródłem niepokoju społeczeństwa nie powinien być poruszany w reklamach. Uważają oni, że obecnie panujące warunki stały się dla każdego zrozumiałe, a przekazy reklamowe z tym związane wywierają niepotrzebną presję i potęgują wśród jej odbiorców złe samopoczucie. Osoby które odpowiedziały, iż słuszne byłoby, aby firmy zaprzestały działań promocyjnych, skupiły się głównie na aspekcie psychologicznym i na tym, jak reklama wpływa na kondycję psychiczną konsumenta.

Sedno przeprowadzonego badania zawiera się $\mathrm{w}$ odpowiedziach na pytanie o wpływ podjętych działań marketingowych przez firmy na zachowania konsumentów w czasie pandemii. Zdaniem większości respondentów zmiany koncepcji strategii marketingowych zdecydowanie nie przyczyniły się do zwiększenia ilości kupowanych przez nich produktów w okresie trwania pandemii. Obserwuje się jednak zwiększenie świadomości ekonomicznej, która przejawia się w bardziej przemyślanych decyzjach zakupowych i zwiększeniu zaangażowania w pomoc lokalnym przedsiębiorcom, na przykład poprzez częstsze zamawianie posiłków na wynos w celu wsparcia branży gastronomicznej.

Intrygujące jest jednak, że mimo przedstawionych wniosków, zdaniem badanych kampanie społeczne widoczne w przekazach reklamowych nie spowodowały u nich znacznego zwiększenia zaangażowania w akcje wspierające walkę z COVID-19. Nasuwa się pewna konkluzja, że konsumenci nie wiążą podejmowanych przez siebie decyzji bezpośrednio z działaniem reklamy. W związku z tym wymienione wcześniej zmiany w zachowaniu społeczeństwa można uznać za wynik perswazyjnego wpływu reklamy na jej odbiorców, a otaczające nas w życiu codziennym przekazy reklamowe w głównej mierze mają wpływ na podświadomość. Potwierdzeniem tej opinii może być fakt, że część osób deklarujących częstsze wybieranie produktów lepszej jakości od czasu pojawienia się koronawirusa sjest zdania, iż nie wynika to bezpośrednio z wpływu reklamy, lecz z autonomicznej woli poprawy swojego zdrowia. Ogólny sposób postrzegania reklamy nie zmienił się, a z badania wynika 
dodatkowo, że obserwowane komunikaty promocyjne nie wpływają na samopoczucie respondentów ani pozytywnie, ani negatywnie.

\section{Podsumowanie}

Celem badania było określenie, czy podjęte przez firmy zmiany w działaniach marketingowych miały wpływ na zachowania konsumentów w czasie trwania pandemii COVID-19. Wyniki wskazują, że działania marketingowe podjęte przez przedsiębiorców na przełomie lat 2020 i 2021 w głównej mierze miały pozytywny wpływ na badaną społeczność. W odpowiedzi na zmiany zachodzące na świecie — w szczególności na zmianę trybu życia znacznej części osób — sposób przekazywania reklamy także w pewnym stopniu się zmienił. Na znaczeniu zyskały wszelkie internetowe działania marketingowe, a skuteczne prowadzenie działań promocyjnych coraz dobitniej wymaga wykorzystania mediów społecznościowych czy strategii e-mail marketingu.

Ponad 90\% osób ankietowanych w spotykanych przekazach reklamowych dostrzegło nawiązania do pandemii COVID-19. Osoby, do których są one kierowane oczekują, by nie pogłębiały one negatywnych nastrojów wynikających z bieżącej, trudnej sytuacji społeczno-gospodarczej. Twórcy kampanii marketingowych powinni dbać o to, aby treść ich przekazów była dostosowana do powagi obecnej sytuacji epidemicznej i była zgodna z zasadami etyki.

Co ciekawe, prawie wszyscy respondenci, bo aż $92 \%$ zgodnie stwierdzili, że firmy nie powinny zaprzestać swoich działań w trakcie trwania pandemii. Konsumenci cenią sobie zaangażowanie dużych przedsiębiorstw w walkę $\mathrm{z}$ wirusem. Ich zdaniem dysponują one wystarczającymi zasobami, aby chociaż skierować produkcję ku wytwarzaniu środków do dezynfekcji czy wesprzeć finansowo odpowiednie organizacje. Co więcej, zaangażowanie firm w budowanie pozytywnej relacji z odbiorcami ich treści, poprzez wzbudzanie zaufania czy poczucia wsparcia w tym trudnym okresie, pozwala stworzyć lojalną więź między klientem a marką.

Trzeba jednak wskazać na pewne ograniczenia związane z możliwością uzyskania efektywniejszych rezultatów przeprowadzonego badania. Jednym z nich jest niewątpliwie panująca w dalszym stopniu pandemia koronawirusa. Społeczeństwo, mając styczność z tym tematem, uważa go za dość uciążliwy i stara się unikać dodatkowych źródeł informacji. Z kolei skupiając się na kierunkach rozwoju dalszych rozważań odnośnie do zachowań konsumentów w czasie pandemii COVID-19, warto rozszerzyć próbę badawczą pod kątem wieku respondentów. Pozwoliłoby to na lepszą ocenę analizowanego tematu, doprecyzowania dotychczasowych wniosków, a nawet sformułowania nowych. Warto też mieć na względzie regularne powtarzanie badań celem dokonania porównań opinii respondentów w ciągu trwania pandemii. 


\section{Bibliografia}

\section{Literatura}

Dennison D., Tobey L., Podręcznik reklamy, Lublin 1997.

Dudzik-Lewicka I., Hofman-Kohlmeyer M., Postrzeganie i skuteczność poszczególnych form reklamy internetowej, „Zeszyty Naukowe Wyższej Szkoły Humanitas. Zarządzanie” 2015, nr 4, s. 207-225.

Filar D., Współczesny marketing. Skuteczna komunikacja i promocja, [w:] Podręcznik dla studentów specjalności Komunikacja urzędowa i biznesowa, red. D. Filar, Lublin 2012.

Furmankiewicz M., Ziuziański P., Newsletter jako efektywne narzędzie e-mail marketingu w zarzadzaniu relacjami z klientami, [w:] Rola informatyki w naukach ekonomicznych i społecznych. Innowacje i implikacje interdyscyplinarne, t. 1, red. Z. E. Zieliński, Kielce 2013, s. 327-334.

Habryń M., Formy reklamy w Internecie, [w:] Estetyka reklamy: reklama w rzeczywistości — rzeczywistość w reklamie, red. M. Ostrowicki, Kraków 2002, s. 285-296.

Kotler P., Marketing. Analiza, planowanie, wdrażanie i kontrola, Poznań 2005.

Lindstrom M., Dziecko reklamy, Warszawa 2005.

Mrożek M., Marketing i sprzedaż produktów pochodzacych z gospodarstwa rolnego, Radom 2020.

Muszyńska J., Jak prowadzić tani i skuteczny marketing w czasach kryzysu gospodarczego, Warszawa 2010.

Nowacki R., Reklama, Warszawa 2005.

Pierścionek Z., Jurek-Stępień S., Czynniki sukcesu polskich przedsiębiorstw na rynkach Unii Europejskiej, Warszawa 2006.

Piosik A., Wspótczesne formy komunikacji w marketingu - guerilla marketing, „Zeszyty Naukowe Uniwersytetu Szczecińskiego. Problemy Zarządzania, Finansów i Marketingu” 2012, nr 21, s. $103-111$.

Rusiecki P., Skuteczny mailing oparty na podstawowych zasadach e-mail marketingu, [w:] Systemy Wspomagania Organizacji SWO 2007, red. T. Porębska-Miąc, H. Sroka, Katowice 2007, s. 279-287.

Starzyńska K., Charakterystyka reklamy w oparciu o jej genezę i cechy, „Zeszyty Naukowe Uniwersytetu Przyrodniczo-Humanistycznego w Siedlcach. Seria: Administracja i Zarządzanie” 2015, nr 106, s. 275-281.

Strużycki M., Heryszek T., Nowoczesna reklama na współczesnym rynku, Warszawa 2007.

\section{Źródła internetowe}

https://digitalmarketinginstitute.com/blog/5-inspiring-covid-19-marketing-campaigns.

https://flstrefa.pl/reklama.html.

https://mobirank.pl/2016/04/28/reklamy-mobilne-adsense-na-poziomie-strony/.

https://www.coca-cola.pl/poznaj-nas-lepiej/komunikaty-prasowe/2020/wstrzymujemy-nasze-dzia-

lania-reklamowe-koronawirus?fbclid=IwAR0OCI_AFII9KRUBFH4LC9ELmfMj65LusLtaafsE25pIVio6SfRpSwSzj9g.

https://www.graziame.com/style/beauty/why-doves-courage-is-beautiful-campaign-is-important.

https://www.ipsos.com/pl-pl/reklama-w-dobie-covid-19.

https://www.loreal.com/pl-pl/poland/articles/group/our-response-to-covid-pl/.

https://www.marketing-interactive.com/designer-behind-viral-covid-19-redesigned-logos-grabs-attention-of-major-brands.

https://www.wirtualnemedia.pl/artykul/najlepsze-reklamy-powstale-w-czasie-pandemii-koronawirusa.

Radzikowski A., Reklama internetowa jako istotny czynnik w skutecznej promocji marki (1), https:// telefirma.pl/reklama-internetowa-jako-istotny-czynnik-skutecznej-promocji-marki-1. 